\title{
Studi FTIR dari Karbonisasi Ampas Bengkuang
}

\author{
Ayu Nidafauziah ${ }^{1}$ M.Iqbal Saputra Gemasih ${ }^{1}$, Umar Kalmar Nizar ${ }^{{ }^{\star}}$, Sri Benti Etika ${ }^{1}$, Desy Kurniawati ${ }^{1}$ \\ Program Studi Kimia, Universitas Negeri Padang, Indonesia \\ E-mail: umarkn@fmipa.unp.ac.id
}

\begin{abstract}
This study aims to manage organic waste as a carbon source. Carbon is a material that is produced by utilizing organic waste so that it is useful and has economic value. Organic waste is solid waste that can still be processed to become useful and economically valuable materials. In this research, carbon has been synthesized from yam waste by calcination method. The carbonization process was carried out at the temperature of the jicama dregs thermal decomposition using TGA and the resulting carbon was characterized by FTIR and using the calculation of the vibrational band area of $C=C$ and $C O$. Based on the FTIR spectra, the carbon produced from the calcination of yam dregs at the variation of the thermal decomposition time still contains organic components as shown by the absorption bands of the FTIR spectra. The results of the diffractogram show that the presence of vibrationfrom $\mathrm{C}=\mathrm{C}$ and $\mathrm{CO}$ from $\mathrm{COOH}$ at wave number 1300-1100 $\mathrm{cm}-1$ which indicates the presence of glycoside bonds in starch. The absorption band of 1600-1500 cm-1 is the vibration of aromatic $C=C$ which indicates the presence of an aromatic ring structure on the polyaromatic carbon structure of calcined jicama dregs carbon. The presence of these peaks indicates that incomplete combustion has occurred which produces incomplete carbon.
\end{abstract}

\section{Keywords: Calcination, Incomplete Carbon, Physicochemical Properties, Yam Pulp}

\section{ABSTRAK}

Penelitian ini bertujuan sebagai pengelolahan limbah organik sebagai sumber karbon. Karbon merupakan suatu material yang diproduksi dengan memanfaatkan limbah organik sehingga bermanfaat dan bernilai ekonomis. Limbah organik merupakan limbah padat yang masih dapat diolah untuk menjadi material yang bermanfaat dan bernilai ekonomis. Pada penelitian ini, karbon telah disintesis dari limbah ampas bengkuang dengan metoda kalsinasi. Proses karbonisasi dilakukan pada suhu dekomposisi termal ampas bengkuang menggunakan TGA dan karbon yang dihasilkan dikarakterisasi dengan FTIR dan mengggunakan perhitungan luas are pita vibrasi $\mathrm{C}=\mathrm{C}$ dan $\mathrm{C}-\mathrm{O}$. Berdasarkan spektra FTIR, karbon yang dihasilkan dari kalsinasi ampas bengkuang pada variasi waktu dekomposisi termalnya masih mengandung komponen organik seperti yang ditunjukan oleh pita-pita serapan spektra FTIR. Hasil difraktogram menunjukan bahwa adanya vibrasi dari $\mathrm{C}=\mathrm{C}$ dan $\mathrm{C}-\mathrm{O}$ dari $\mathrm{COOH}$ pada bilangan gelombang $1300-1100 \mathrm{~cm}^{-1}$ yang menunjukkan adanya ikatan glikosida dalam pati. Pita serapan 1600$1500 \mathrm{~cm}^{-1}$ adalah vibrasi dari $\mathrm{C}=\mathrm{C}$ aromatis yang menandakan keberadaan struktur cincin aromatik pada struktur karbon poliaromatik karbon ampas bengkuang hasil kalsinasi. Adanya puncak-puncak tersebut menandakan bahwa telah terjadinya pembakaran tidak sempurna yang menghasilkan carbon incomplit.

Kata Kunci: Ampas Bengkuang, Carbon Incomplit, Kalsinasi, Sifat Fisikokimia

\section{PENDAHULUAN}

Karbon merupakan suatu material yang diproduksi dengan memanfaatkan limbah organik. Produksi karbon dari limbah organik ini sangat menguntungkan karena bernilai ekonomis. Sumber karbon yang telah dilaporkan seperti ampas bengkuang, biji alpukat, ampas tebu. Saat ini sangat dikembangkan sumber karbon sebagai pengolahan limbah organik sehingga menjadi tujuan dalam penelitian ini. Produksi karbon yang berasal dari limbah organik dapat menghemat akan biaya produksi. Semua dari sumber karbon telah dilaporkan sebagai sebagai katalis karbon yang baik (Pauline \& Joseph, 2020).

Salah satu limbah yang dimanfaatkan seperti pada tanaman Bengkuang (Pachyrhizus erosus) yang termasuk jenis umbi-umbian yang berpotensi sebagai bahan baku pati yang termasuk polisakarida. Bengkuang banyak diolah sebagai limbah organik dengan memanfaatkan ampasnya. Ampas bengkuang banyak mengandung pati, selulosa, lignin, hemiselulosa dan asam lemak. Banyaknya pati yang terdapat dalam ampas bengkuang sangat berpotensi sebagai sumber karbon.

Karbon ampas bengkuang yang dihasilkan dibuat dengan metode kalsinasi. Kalsinasi adalah proses penguraian material atau suatu molekul organik pada pemanasan suhu tinggi dengan atau tidak adanya oksigen (dalam suasana inert). Adanya oksigen selama proses kalsinasi menghasilkan dampak positif dan negatif. Dampak positifnya seperti prosesnya cepat dan suhu rendah sedangkan pada dampak negatif berkaitan dengan keberadaan oksigen yang menyebabkan pembakaran sempurna (Miao et al., 2018).

Proses karbonisasi menggunakan furnace. Proses karbonisasi digunakan untuk pembentukan cincin polisiklik aromatik yang berfungsi sebagai situs. Beberapa parameter yang mempengaruhi sifat-sifat karbon diantaranya suhu kalsinasi, waktu kalsinasi, laju pemanasan dan laju alir gas nitrogen (Qi et al., 2019).

Suhu dan waktu kalsinasi sangat mempengaruhi kualitas karbon yang dihasilkan. Waktu kalsinasi yang biasa digunakan berkisaran 1 hingga 14 jam. Penggunaan waktu terlalu lama akan mengakibatkan pengerasan pada struktur karbon sehingga terjadinya hambatan perlekatan gugus $-\mathrm{SO}_{3} \mathrm{H}$ saat menghasilkan katalis (Lokman et al., 2014).

Pada penelitian ini dilaporkan preparasi karbon dari ampas bengkuang melalui proses karbonisasi menggunakan metode kalsinasi. Suhu kalsinasi ditetapkan daru stabilitas termal yang didapatkan pada TGA/DTA. Daerah dekomposisi lingkungan organik dari karbon ampas bengkuang sebagai variasi waktu 
kalsinasi untuk menghasilkan karbon. Karbon yang dihasilkan dikarakterisasi dengan FTIR dan dihitung dengan luas area pita vibrasi $\mathrm{C}=\mathrm{C}$ dan $\mathrm{C}-\mathrm{O}$.

\section{METODE}

Penelitian ini merupakan penelitian eksperimental laboratorium dengan metode uji kalsinasi dilakukan pada bulan September 2020 sampai Mei 2021 dan lokasi penelitian ini dilakukan di Laboratorium Penelitian Jurusan Kimia Fakultas Matematika dan Ilmu Pengetahuan Alam (FMIPA) Universitas Negeri Padang. Sampel yang digunakan adalah ampas bengkuang yang diperoleh dari limbah pembuatan jus disalah satu penjualan jus di Tunggul Hitam, Padang.

Peralatan yang digunakan yaitu, cawan penguap, aluminium foil, lumpang dan alu, serta furnance. Untuk karakterisasi digunakan TGA, FTIR dan Hubungan luas area pita vibrasi $\mathrm{C}=\mathrm{C}$ dan $\mathrm{C}-\mathrm{O}$. Bahan yang digunakan adalah limbah ampas bengkuang.

Sebelum dikalsinasi ampas bengkuang dikeringkan dan dihaluskan. Sampel ampas bengkuang kemudian dikarakterisasi dengan TGA untuk memperoleh stabilitas termalnya daerah dekomposisi lingkungan organik. Sampel discan pada suhu $25-575^{\circ} \mathrm{C}$ dengan laju pemanasan $30^{\circ} \mathrm{C} /$ menit (Farabi et al., 2019). Berdasarkan data TGA dipilih variasi suhu kalsinasi yang dimulai dari awal terdekomposisinya lingkungan organic hingga sebelum sampel terdekomposisi sempurna. Sampel dikalsinasi dengan variasi waktu 1 jam, 2 jam, 3 jam, 4 jam dan 5 jam dengan suhu $250^{\circ} \mathrm{C}$ dan kemudian disimpan dalam desikator.

Sebelumnya karakterisasi dengan TGA hanya dilakukan untuk sampel ampas bengkuang untuk menentukan daerah dekomposisi termalnya. Sampel karbon yang dihasilkan dari variasi waktu kalsinasi dan dikarekterisasi dengan FTIR dan Perhitungan Luas Pita Area Vibrasi C=C dan C-O. Karakterisasi dengan FTIR dilakukan pada bilangan gelombang $4000-600 \mathrm{~cm}^{-1}$ (Wang et al., 2019). Sampel yang digunakan untuk karakterisasi dengan FTIR harus dalam bentuk powder.

Tabel 1. Sampel Karbon

\begin{tabular}{llcc}
\hline No. & Sampel & Waktu & Kode \\
\hline 1 & Karbon Ampas Bengkuang & $1 \mathrm{~h}$ & K-AB 1 h \\
2 & Karbon Ampas Bengkuang & $2 \mathrm{~h}$ & K-AB 2 h \\
3 & Karbon Ampas Bengkuang & $3 \mathrm{~h}$ & K-AB 3 h \\
4 & Karbon Ampas Bengkuang & $4 \mathrm{~h}$ & K-AB 4 h \\
5 & Karbon Ampas Bengkuang & $5 \mathrm{~h}$ & K-AB 5 h \\
\hline
\end{tabular}

\section{HASIL DAN PEMBAHASAN}

Karakterisasi TGA/DTA dilakukan untuk mengetahui dekomposisi termalnya sehingga didapatkan rentangan suhu yang akan digunakan dalam proses karbonisasi ampas bengkuang dengan metode kalsinasi, untuk mendapatkan carbon incomplit. Berdasarkan Gambar 1, termogram yang dihasilkan dapat dibagi atas tiga tahap. Penjelasan dari Spektrum TGA/DTA dapat dilihat pada gambar dibawah.

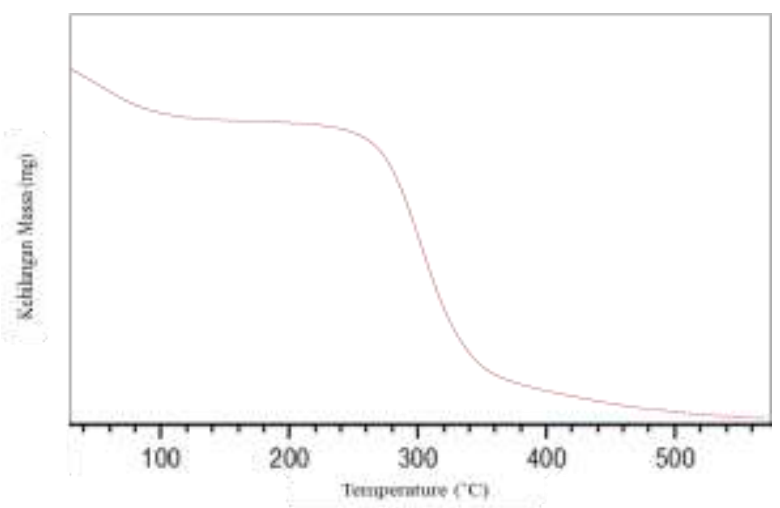

Gambar 1. Spektra TGA Sampel Ampas Bengkuang 


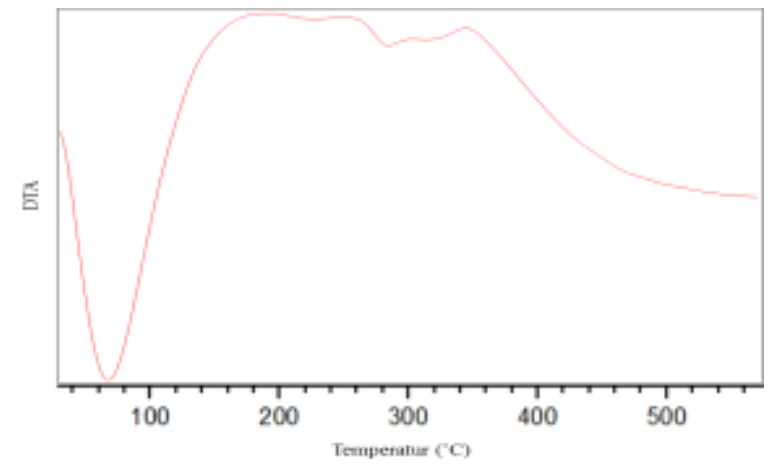

Gambar 2. Spektra DTA Sampel Ampas Bengkuang

Dekomposisi termal untuk sampel ampas bengkuang ditentukan dengan TGA seperti yang ditunjukan pada Gambar 1. Berdasarkan Gambar 1, pada suhu 25 hingga $150^{\circ} \mathrm{C}$ merupakan daerah terjadinya kehilangan massa dari air yang terserap pada permukaan sampel ampas bengkuang. Hal ini ditunjukkan adanya pita endotermik pada DTA didaerah tersebut. Pada suhu antara $150^{\circ} \mathrm{C}$ hingga $350^{\circ} \mathrm{C}$ merupakan daerah pembakaran senyawa organic akibat naiknya temperature. Dekomposisi dimulai pada suhu $250^{\circ} \mathrm{C}$. Seperti terlihat pada gambar, grafik mengalami penurunan hingga suhu $500^{\circ} \mathrm{C}$ yang menunjukan bahwa senyawa organik telah terdekomposisi sempurna (Farabi et al., 2019). Berdasarkan hasil ini, maka ditetapkanlah suhu untuk kalsinasi untuk menghasilkan karbon dari sampel ampas bengkuang adalah pada suhu $250^{\circ} \mathrm{C}$.

Ampas bengkuang mengandung protein, asam lemak, karbohidrat (pati, selulosa, hemiselulosa, dan lignin) (Noman et al., 2007). Karbonisasi yang dilakukan ada ampas bengkuang adalah karbonisasi yang tidak sempurna. Artinya, karbon yang dihasilkan masih mengandung komponen organik. Karbon ampas bengkuang dikarakterisasi dengan FTIR untuk memastikan bahwa ampas bengkuang yang dihasilkan terkarbonisasi tidak sempurna. Berdasarkan komposisi tersebut dapat diinterpretasikan pita-pita serapan pada FTIR dari ampas bengkuang seperti yang ditunjukan oleh Gambar 3. Pada spektrum ampas bengkuang terdapat pita-pita vibrasi utama pada wilayah $3300 \mathrm{~cm}^{-1}, 1600 \mathrm{~cm}^{-1}, 1250 \mathrm{~cm}^{-1}$. Puncak pada $3400-3200 \mathrm{~cm}^{-1}$ merupakan vibrasi dari $\mathrm{OH}$ yang berasal dari uap air yang terabsobsi selama proses preaprasi sampel saat karakterisasi (Nizar et al., 2018) . Adanya puncak lemah yang berada pada daerah $3000-2800 \mathrm{~cm}^{-1}$ menunjukkan vibrasi C-O dari pati. Hal ini dikarenakan berhasilnya dekomposisi sampel ampas bengkuang menjadi karbon. (Kumar et al., 2020).

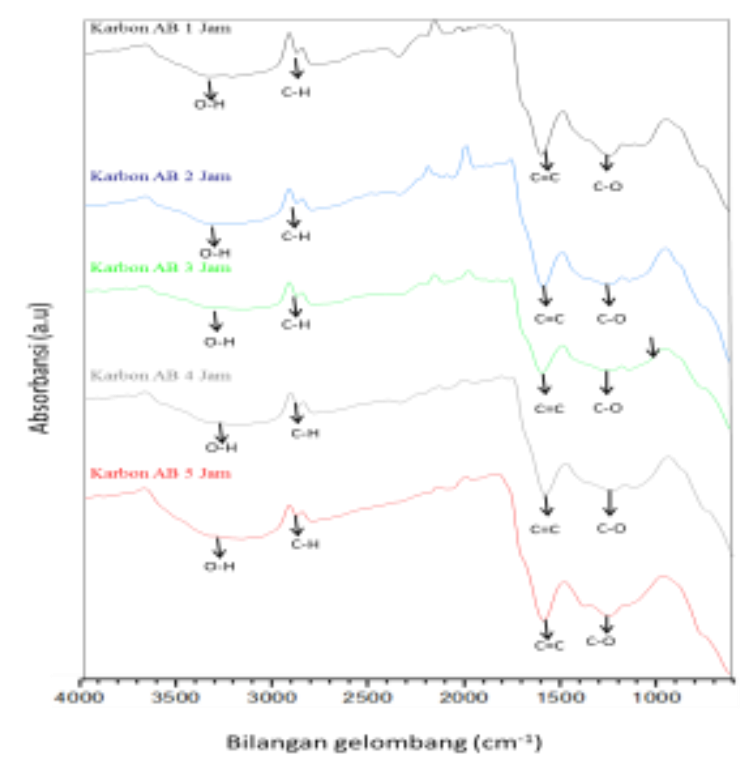

\section{Gambar 2. Spektra FTIR Karbon Kulit Ubi Kayu (K-AB)}

Spektrum ampas bengkuang menunjukan terjadinya perobahan struktur akibat meningkatnya waktu kalsinasi. Dimana puncak C-O semakin menghilang dengan meningkatnya waktu kalsinasi. Spektrum karbon ampas bengkuang hasil kasinasi juga terdapat pita-pita vibrasi utama pada bilangan gelombang $1799-1496 \mathrm{~cm}^{-1}$ adalah vibrasi dari $\mathrm{C}=\mathrm{C}$ aromatis yang menandakan keberadaan struktur cincin aromatik pada struktur karbon poliaromatik karbon ampas bengkuang hasil kalsinasi. Pita serapan 1502-1192 $\mathrm{cm}^{-1}$ menunjukkan ikatan C-O dari gugus fungsi C-O-C dari ikatan glikosidik dalam pati (Kefas et al., 2019). 
Perhitugan luas area pita vibrasi $\mathrm{C}=\mathrm{C}$ dan $\mathrm{C}-\mathrm{O}$ dilakukan dengan semi kuantitatif yang bertujuan untuk mengetahui luas area pada $\mathrm{C}=\mathrm{C}$ dan $\mathrm{C}-\mathrm{O}$, dimana apabila waktu kalsinasi semakin meningkat diindikasikan bahwa luas area $\mathrm{C}-\mathrm{O}$ akan semakin mengecil atau tidak tampak sedangkan pada luas area $\mathrm{C}=\mathrm{C}$ akan semakin muncul atau tampak, Ini dikarenakan semakin tingginya waktu kalsinasi maka ikatan glikosida yang terdapat pada ampas bengkuang akan putus (Akinfalabi et al., 2017).

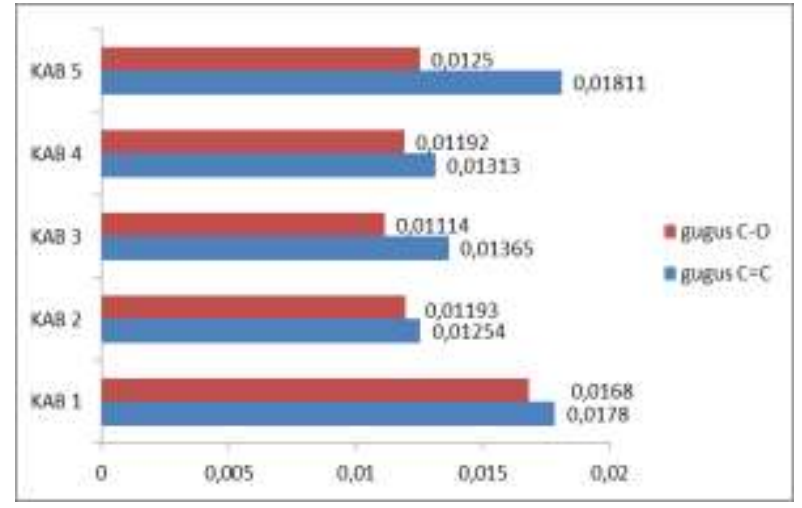

Gambar 4. Pita Vibrasi $\mathrm{C}=\mathrm{C}$ dan $\mathrm{C}-\mathrm{O}$

Berdasarkan Gambar 4. Merupakan daerah vibrasi dari $\mathrm{C}=\mathrm{C}$ dan C-O dalam karakterisasi FTIR. Luas area pita vibrasi dilakukan dengan aplikasi origin. Hasil yang didapatkan dari pengolahan menggunakan origin didapatkan luas daerah KAB 5 untuk pita $C=C$ yaitu sebesar $0,01811 \mathrm{~cm}^{2}$ dan pita $\mathrm{C}-\mathrm{O}$ sebesar $0,0125 \mathrm{~cm}^{2}$ ini menandakan bahwa ampas bengkuang menjadi karbon dengan hasil yang baik pada waktu kalsinasi 5 jam.

Kesimpulan

Penelitian ini bertujuan untuk mensintesis karbon ampas bengkuang dengan proses karbonisasi dengan metode kalsinasi pada suhu $250^{\circ} \mathrm{C}$ yang didapatkan dari spektrum TGA/DTA. Analisis menggunakan FTIR bertujuan untuk mengetahui gugus fungsi yang ada pada karbon ampas bengkuang dengan variasi waktu kalsinasi. Oleh karena itu, perlu adanya studi untuk membahas FTIR karbon ampas bengkuang.

\section{REFERENSI}

1. Akinfalabi, S. I., Rashid, U., Yunus, R., \& Taufiq-Yap, Y. H. (2017). Synthesis of biodiesel from palm fatty acid distillate using sulfonated palm seed cake catalyst. Renewable Energy, 111, 611-619. https://doi.org/10.1016/j.renene.2017.04.056

2. Farabi, M. S. A., Ibrahim, M. L., Rashid, U., \& Taufiq-Yap, Y. H. (2019). Esterification of palm fatty acid distillate using sulfonated carbon-based catalyst derived from palm kernel shell and bamboo. Energy $\begin{array}{llll}\text { Conversion and } & \text { 181(December 2018), }\end{array}$ https://doi.org/10.1016/j.enconman.2018.12.033

3. Kefas, H. M., Yunus, R., Rashid, U., \& Taufiq-Yap, Y. H. (2019). Enhanced biodiesel synthesis from palm fatty acid distillate and modified sulfonated glucose catalyst via an oscillation flow reactor system. Journal of Environmental Chemical Engineering, 7(2), 102993. https://doi.org/10.1016/j.jece.2019.102993

4. Kumar, V., Al-Gheethi, A., Asharuddin, S. M., \& Othman, N. (2020). Potential of cassava peels as a sustainable coagulant aid for institutional wastewater treatment: Characterisation, optimisation and technoeconomic analysis. Chemical Engineering Journal, 127642. https://doi.org/10.1016/j.cej.2020.127642

5. Lokman, I. M., Rashid, U., Yunus, R., \& Taufiq-Yap, Y. H. (2014). Carbohydrate-derived solid acid catalysts for biodiesel production from low-cost feedstocks: A review. Catalysis Reviews - Science and Engineering, 56(2), 187-219. https://doi.org/10.1080/01614940.2014.891842

6. Miao, Z., Li, Z., Liu, D., Zhao, J., Chou, L., Zhou, J., \& Zhuo, S. (2018). An efficient ordered mesoporous molybdate-zirconium oxophosphate solid acid catalyst with homogeneously dispersed active sites: Synthesis, characterization and application. Journal of Colloid and Interface Science, 526, 145-157. https://doi.org/10.1016/j.jcis.2018.04.107

7. Nizar, U. K., Hidayatul, J., Sundari, R., Bahrizal, B., Amran, A., Putra, A., Latisma Dj, L., \& Dewata, I. (2018). The Effect of Titanium Tetrahedral Coordination of Silica-Titania Catalyst on the Physical Properties of Biodiesel. IOP Conference Series: Materials Science and Engineering, 335(1). https://doi.org/10.1088/1757899X/335/1/012036

8. Noman, A. S. M., Hoque, M. A., Haque, M. M., Pervin, F., \& Karim, M. R. (2007). Nutritional and anti-nutritional components in Pachyrhizus erosus L. tuber. Food Chemistry, 102(4), 1112-1118. https://doi.org/10.1016/j.foodchem.2006.06.055

9. Pauline, A. L., \& Joseph, K. (2020). Hydrothermal carbonization of organic wastes to carbonaceous solid fuel A review of mechanisms and process parameters. Fuel, 279(December 2019), 118472. https://doi.org/10.1016/j.fuel.2020.118472

10. Qi, X., Yan, L., Shen, F., \& Qiu, M. (2019). Mechanochemical-assisted hydrolysis of pretreated rice straw into 
glucose and xylose in water by weakly acidic solid catalyst. Bioresource Technology, 273, 687-691. https://doi.org/10.1016/j.biortech.2018.11.011

11. Wang, Y. T., Yang, X. X., Xu, J., Wang, H. L., Wang, Z. B., Zhang, L., Wang, S. L., \& Liang, J. L. (2019). Biodiesel production from esterification of oleic acid by a sulfonated magnetic solid acid catalyst. In Renewable Energy (Vol. 139). Elsevier Ltd. https://doi.org/10.1016/j.renene.2019.02.111 